\title{
NO SUPPORT FOR A GENETIC BASIS OF MANDIBLE CROSSING DIRECTION IN CROSSBILLS (LOXIA SPP.)
}

\author{
Pim Edelaar, ${ }^{1,2,6}$ Erik Postma, ${ }^{3}$ Peter Knops, ${ }^{4}$ and Ron Phillips ${ }^{5}$ \\ ${ }^{1}$ Department of Biology, New Mexico State University, Las Cruces, New Mexico 88003, USA; \\ ${ }^{2}$ Department of Zoology, University of British Columbia, Vancouver, British Columbia V6T 1Z4, Canada; \\ ${ }^{3}$ Centre for Terrestrial Ecology, Netherlands Institute of Ecology, 6666 ZG Heteren, The Netherlands; \\ ${ }^{4}$ Molsteeg 37, 6369 GL Simpelveld, The Netherlands; and \\ ${ }^{5} Y e t h o l m$, St. Catherine's Place, Elgin, Moray, Scotland, United Kingdom
}

\begin{abstract}
Aвstract. - Unusual among birds, the bill tips in crossbills (Loxia spp.) overlap in the vertical plane, with the tip of the lower mandible to either the left or right of the tip of the upper mandible when viewed from above. Patterns observed in wild populations and experimental foraging data suggest that a 1:1 ratio of left- to rightcrossing individuals is maintained by frequency-dependent natural selection in some populations, and that genetic drift causes deviation from a 1:1 ratio in other populations. Both processes require a genetic basis for this remarkable polymorphism, yet few data are available that address whether, and how, mandible crossing direction is heritable. To test for a genetic basis of this trait (single or quantitative, autosomal or sex-linked), we analyzed resemblance in mandible crossing direction between related captive-bred individuals of several crossbill taxa with standard statistical techniques as well as modern animal model methodology. Surprisingly, we did not find statistically significant support for a genetic basis of mandible crossing direction. Comparisons of the ratio of left- to right-crossing males and females in wild populations also did not support a sex-linked quantitative genetic basis. We conclude that mandible crossing direction may have uncharacteristically low heritability, but we cannot rule out that it is nongenetically determined. Received 27 August 2004, accepted 27 March 2005.
\end{abstract}

Key words: animal model, crossbill, heritability, Loxia, mandible crossing direction.

La Dirección de Cruzamiento de la Mandíbula en las Especies de Loxia no Presenta Base Genética

Resumen.-De modo inusual entre las aves, las puntas del pico de las especies de Loxia se superponen en el plano vertical, y la punta de la mandíbula inferior está cruzada ya sea hacia la derecha o a la izquierda de la punta de la mandíbula superior. Los patrones observados en las poblaciones silvestres y los datos de experimentos de forrajeo sugieren que la relación 1:1 de los individuos con cruzamiento hacia la izquierda o hacia la derecha se mantiene el algunas poblaciones por selección natural dependiente de la frecuencia, y que la deriva génica causa desviaciones de la relación 1:1 en otras poblaciones. Ambos procesos requieren una base genética para este destacable polimorfismo, aunque existen pocos datos que indiquen si el cruzamiento de la mandíbula es heredable, y cómo sucede esto. Para evaluar la base genética de este caracter (simple o cuantitativo, autosómico o ligado al sexo), analizamos el parecido en la dirección del cruzamiento de la mandíbula entre individuos relacionados de varios taxa de Loxia criados en cautiverio usando técnicas estadísticas

${ }^{6}$ Present address: Centro Nacional Patagonico, U9120 ACV Puerto Madryn, Argentina. E-mail: w.m.c.edelaar @umail.leidenuniv.nl 
estándar así como metodologías modernas de modelos animales. Sorprendentemente, no encontramos evidencias estadísticamente significativas que indiquen que la dirección de cruzamiento de la mandíbula tiene una base genética. Las comparaciones del cociente de individuos con cruzamiento hacia la izquierda y hacia la derecha en machos y hembras en las poblaciones silvestres tampoco apoyaron la existencia de una base genética cuantitativa ligada al sexo. Concluimos que la dirección de cruzamiento de la mandíbula podría tener un grado de heredabilidad atípicamente bajo, pero no podemos descartar que no esté genéticamente determinada.

MECHANISMS THAT PRODUCE and maintain discrete polymorphisms in wild populations have long fascinated evolutionary biologists. Crossbills (Loxia spp.) are unique among birds in that the bill shows a pronounced asymmetry in the vertical plane (for a few other examples, see Tordoff 1954, Hatch 1985): when viewed from the side, the distal end of the lower mandible is twisted sideways and overlaps with the distal end of the upper mandible. Mandible crossing in crossbills is an adaptation for foraging on partly closed conifer cones (Benkman and Lindholm 1991). Crossbills use the tips of their crossed mandibles to bite between cone scales, after which they laterally abduct the lower mandible to the side to which it crosses. This action separates the cone scales and exposes the seeds at the scales' bases; the crossbill can then lift out the seeds with its tongue, and husk and swallow them (Benkman 1996).

In each individual, the lower mandible is twisted to either the left or right (defined as the position of the tip of the lower mandible in relation to the tip of the upper mandible). Both position types occur in every crossbill population studied, so the maintenance of this polymorphism necessitates an evolutionary explanation. Benkman (1996) suggested that frequencydependent selection favors the maintenance of each type in a population. If perch sites are limited and cones are firmly attached to the tree, the mandible crossing direction limits foraging birds to efficiently exploiting only part of the cone, because the lower mandible can be abducted to one side only and crossbills orient themselves so that the lower mandible is pointed toward the cone axis. Birds that visit cones previously foraged on by birds with the same mandible crossing direction would thus suffer from reduced food intake rates because of resource depletion. Low food intake results in higher mortality and lower reproductive rates, favoring birds of the rarer mandible crossing direction and resulting in frequency-dependent selection that is stable at a 1:1 ratio of mandible crossing directions. Experimental foraging data on crossbills support the mechanism of partial depletion caused by the mandible crossing direction. On the other hand, if the cone can be removed or twisted, no such partial depletion occurs and genes for leftor right-crossing have equal fitness. Because of finite population sizes, the frequency of genes determining mandible crossing direction is affected by genetic drift, and deviations from a 1:1 ratio may occur. In support of this argument, some crossbill taxa that commonly remove or twist cones show ratios of mandible crossing that deviate significantly from a 1:1 ratio (with over-representation of either left- or rightcrossing individuals), whereas populations feeding on firmly attached cones do not deviate from a 1:1 ratio (Benkman 1996).

One critical assumption in this evolutionary explanation for the observed ratios of left- to right-crossing birds in populations is that mandible crossing direction has a heritable component: otherwise, neither an evolutionary response to frequency-dependent selection nor genetic drift could occur. Whether mandible crossing direction in crossbills has a genetic basis has been the focus of much speculation but of few empirical studies (Benkman 1996). Data on the mandible crossing direction of parents and offspring has been published only for two pairs of White-winged Crossbills (Loxia leucoptera leucoptera; Benkman 1988) and one pair of Red Crossbills (L. curvirostra; Groth 1992) from North America. Assuming that a genetic mechanism determining mandible crossing evolved only once in the genus Loxia (the most parsimonious assumption; Groth 1992), these combined observations on White-winged and Red crossbills exclude the existence of a dominant allele for right-crossing but support leftcrossing dominance, sex-linked heritability, and a quantitative genetic basis. 
These limited data are insufficient for deciding whether, and how, mandible crossing direction is genetically determined. Here, we analyze various data sets to explore the genetic basis of mandible crossing direction in crossbills.

\section{Methods}

Most of our data pertain to results from captive breeding of a number of different crossbill taxa. A large advantage is that all pairs were housed separately, ensuring the genetic relationship between parents and offspring (no extrapair fertilizations). These crossbills were offspring from birds originally caught in their native range (depending on taxon involved: Russia, Germany, Austria, China, or Scotland) and since bred without hybridization by amateurs in Scotland, The Netherlands, and Belgium. All birds were individually banded and kept under license. Birds were fed a commercial birdseed mixture.

We first determined whether a single gene could explain mandible crossing direction. Only for two species are the data sufficient for evaluating all possibilities. Given the scarcity of previously published data and the possibility of interspecific differences, we present all our data from a number of different crossbill taxa for future reference.

If a single gene cannot explain the observed patterns of mandible crossing direction of parents and offspring, perhaps several genes can. It is not unusual that multiple genes determine a discrete, bimodal trait such as mandible crossing direction. In such cases, it is assumed that the phenotypic expression of the binary trait is determined by an underlying, normally distributed trait. Whether the underlying trait falls below or above a certain threshold will determine the observed phenotype-here, the direction of crossing (Lynch and Walsh 1998). We tested for a quantitative genetic basis of mandible crossing direction using a large data set from a population of Scottish Crossbills (L. scotica; captive bred for four generations as described above). Analyses are based on 61 individuals, with 15 sires and 15 dams (one male and one female had two different mates, making 16 pairs). We first calculated the heritability of mandible crossing direction by means of traditional parent-offspring regressions (Lynch and Walsh 1998). In these analyses, each individual offspring has been used as an individual data point. This may inflate our $h^{2}$ estimates (but, as will be clear below, this is not a problem), because siblings may resemble each other as a result not only of shared genes, but also of a shared environment. However, our limited sample size did not allow for using family means. Regressions were performed using both mean and single parent values to test for (female) sex-limited inheritance. Our tests were two-sided, but one-sided testing did not alter the conclusions.

More information on relatives is available in our pedigree than is used by the parentoffspring regression. We could compare, for example, siblings and half siblings, or offspring and their grand- and great-grandparents. Furthermore, some individuals raised several broods with different partners. Animal model methodology has been developed specifically for the quantification of genetic parameters in such complex, multi-generational pedigrees, and allows for the simultaneous use of all available information (Lynch and Walsh 1998). An animal model can accommodate inbreeding, selection, and (more importantly) nonrandom mating, providing us with the most powerful method available to test for the presence of a genetic basis of mandible crossing direction. Additive genetic, as well as additional nongenetic, variance components were estimated for mandible crossing direction in Scottish Crossbills by means of restricted maximum likelihood (REML) techniques, using the software package VCE4 (Groeneveld 1995).

Finally, as an alternative test for sex-linked inheritance of mandible crossing direction, we compared ratios of left- to right-crossing birds between males and females in wild populations. This difference in ratios between the sexes will be large when a single sex-linked gene determines the trait, whereas a small yet significant difference between the sexes indicates the effects of multiple genes with only a small proportion of sex-linked genes. We compared ratios between males and females using both published and new data.

\section{Results}

In Table 1, we provide data on mandible crossing direction from parents and offspring of 2 pairs of White-winged (Two-barred) Crossbills (L. leucoptera bifasciata), 11 pairs of European 
TABLE 1. Mandible crossing direction ( $\mathrm{R}=$ right-crossing, $\mathrm{L}=$ left-crossing) of parents and offspring of White-winged (Two-barred), European Red, Himalayan Red, and Parrot crossbills. Offspring of different broods of the same pair (full siblings) are lumped; results involving offspring with one different parent (half siblings) are given separately. Numbers in parentheses indicate parents involved in multiple pairings. Dashes indicate that no offspring of that sex were produced; question mark indicates that mandible crossing direction is unknown.

\begin{tabular}{|c|c|c|c|c|c|}
\hline Pair number & Father & Mother & Son & Daughter & Sex unknown \\
\hline \multicolumn{6}{|c|}{ White-winged Crossbill } \\
\hline 1 & $\mathrm{R}$ & $\mathrm{L}$ & RRRL & RRL & \\
\hline 2 & $\mathrm{~L}$ & $\mathrm{R}$ & & & LLR \\
\hline \multicolumn{6}{|c|}{ European Red Crossbill } \\
\hline 3 & $\mathrm{R}$ & $\mathrm{R}$ & RL & RRRRRRL & \\
\hline 4 & $\mathrm{R}$ & $\mathrm{R}$ & RLL & RRRRLLLL & \\
\hline 5 & $\mathrm{R}$ & $\mathrm{R}$ & RL & RRRLLL & \\
\hline 6 & $\mathrm{R}(1)$ & $\mathrm{R}$ & $\mathrm{L}$ & $\mathrm{L}$ & \\
\hline 7 & $\mathrm{R}(1)$ & $\mathrm{L}(2)$ & - & RLL & \\
\hline 8 & $\mathrm{R}$ & $\mathrm{L}$ & & & RLL \\
\hline 9 & $\mathrm{~L}$ & $\mathrm{R}$ & & & RRRRL \\
\hline 10 & $\mathrm{~L}$ & $\mathrm{R}$ & & & RL \\
\hline 11 & $\mathrm{~L}$ & $\mathrm{~L}(2)$ & $\mathrm{R}$ & $\mathrm{R}$ & \\
\hline 12 & $\mathrm{~L}$ & $\mathrm{~L}$ & RRL & RL & \\
\hline 13 & $?$ & $\mathrm{~L}(2)$ & $\mathrm{L}$ & $\mathrm{R}$ & \\
\hline \multicolumn{6}{|c|}{ Himalayan Red Crossbill } \\
\hline 14 & $\mathrm{~L}$ & $\mathrm{~L}$ & LL & RRRL & \\
\hline \multicolumn{6}{|c|}{ Parrot Crossbill } \\
\hline 15 & $\mathrm{R}$ & $\mathrm{L}$ & RRLL & RRRLL & \\
\hline 16 & $\mathrm{R}$ & $\mathrm{L}$ & & & RRL \\
\hline
\end{tabular}

Red Crossbills (L. curvirostra curvirostra), 1 pair of Himalayan Red Crossbills (L. c. himalayensis), and 2 pairs of Parrot Crossbills (L. pytyopsittacus). These data show that, at least for the Red Crossbill, mandible crossing direction is not simply determined by a single gene. Results for pairs 3-6 in Table 1 exclude a single, autosomal left-dominant gene (both parents have rightcrossing mandibles yet produce left-crossing offspring). Pairs 11 and 12 exclude a single, autosomal right-dominant gene (both parents have left-crossing mandibles yet produce rightcrossing offspring). Pairs 3-7, 11, and 12 combined also rule out determination of mandible crossing direction by a single sex-linked gene (both left- and right-crossing males sired daughters with a mandible crossing direction opposite to their own). The data are insufficient to test whether the same pattern holds for the other crossbill taxa in Table 1.

Similarly, single gene inheritance could not explain the observed pattern in Scottish Crossbills (data not shown). With regards to a quantitative genetic basis of mandible crossing direction, the heritability estimates based on parent-offspring regressions $( \pm \mathrm{SE})$ were low (and even negative) and nonsignificant: mean parent-offspring: $h^{2}=-0.094 \pm 0.10(t=-0.90$, $P=0.37)$; father-offspring: $h^{2}=-0.003 \pm 0.16(t=$ -0.02, $P=0.99)$; mother-offspring: $h^{2}=-0.213 \pm$ $0.16(t=-1.35, P=0.19)$. Hence, there is no support for a major quantitative genetic basis of mandible crossing direction. Estimating heritabilities for a binary trait using the observed phenotypes instead of the underlying genetic scale usually leads to an underestimate of heritability, and estimated heritabilities should be multiplied with a correction factor (Lynch and Walsh, 1998). Here, however, this would result only in more negative heritability estimates.

Using the powerful animal-model methodology, we found no evidence of significant heritability, nor of a brood, maternal, or paternal effect. Although analyses reached optimal convergence, variance component estimates were all equal to zero. As with the outcome 
for parent-offspring regressions (and with the same assumptions; also see below), there is no support for an autosomal or sex-linked genetic basis of mandible crossing direction.

Ratios of mandible crossing direction between males and females are presented in Table 2. In contrast to Groth (1992), we initially found statistical support for a difference in the ratios of mandible crossing between males and females, both in White-winged Crossbills from North America and in Red Crossbills from the Pyrenees (Spain). However, if we corrected for multiple testing (alpha $[\alpha]=0.05$ per number of comparisons), none of the observed differences in Table 2 remain significant. Correcting for multiple testing may be too conservative if studies with low and high statistical power are all valued equally. Yet even if we restrict the comparisons to the three studies with the largest sample sizes, the difference in ratios between males and females are not significant when correcting for multiple testing. Hence, in line with all other results, there is no support for a sex-linked quantitative genetic basis of mandible crossing direction.

\section{Discussion}

We did not find statistical support for a quantitative genetic basis of mandible crossing direction in Scottish Crossbills. However, it is important to realize that statistical power is relatively low, for two reasons. (1) Sample size is sufficient to detect only heritabilities of 0.20 0.30 , indicated by the standard errors of 0.10 0.15 . However, heritabilities for morphological traits in birds typically range between 0.4 and 0.6 (Merilä and Sheldon 2001). (2) Almost all pairs are made up of a left- and a right-crossing individual, and such pairs are not very informative because one expects, on average, a 1:1 ratio of mandible crossing direction in the offspring, unless there is strong sex linkage or if the ratio normally observed in the population deviates strongly from a 1:1 ratio (which it did not in our population). However, we also found no significant heritability for the three pairs in which both parents have the same mandible crossing direction: mean parent-offspring: $h^{2}=-0.238 \pm$ $0.293(t=-0.81, P=0.43)$.

On the whole, we could not confirm that mandible crossing direction is determined by a single gene (autosomal or sex-linked). To our surprise, analysis of data from birds bred in captivity also provides no support for a major autosomal or sex-linked quantitative genetic basis. The apparent lack of a quantitative sex-linked genetic basis for mandible crossing direction is further supported by the comparisons of ratios of left- to right-crossing males and females in the wild. Our results may be explained by a comparatively low heritability for mandible crossing direction. Any future tests for a genetic basis for mandible crossing direction should be based on

TABle 2. Number of crossbills with left- (L) and right-crossing (R) mandibles in different populations by sex. $\widehat{\delta} \%-q \%$ is the difference between the proportion of right-crossing males and the proportion of right-crossing females. $\chi^{2}$ is the chi-square goodness-of-fit (with $\mathrm{df}=1$ ) for the comparison of these proportions between males and females (see text for discussion of statistical significance). Types A, C, and X are European Red Crossbill vocal types, which may represent evolutionarily independent lineages (see Groth 1993, Robb 2000, Edelaar et al. 2003). Several such vocal types are included in the numbers provided by Groth (1992) (North America), and this may be true also for Terpstra (The Netherlands).

\begin{tabular}{|c|c|c|c|c|c|c|c|}
\hline Taxon & $\widehat{O} \mathrm{~L}$ & $\widehat{O} \mathrm{R}$ & ㅇ L & $q \mathrm{R}$ & ऽ\%-१\% & $\chi^{2}$ & $\begin{array}{l}\text { Reference/ } \\
\text { unpublished data }\end{array}$ \\
\hline L. l. leucoptera & 100 & 311 & 90 & 198 & +6.2 & 4.10 & Benkman \\
\hline L. curvirostra & 1182 & 1074 & 713 & 678 & -1.4 & 0.44 & Groth (1992) \\
\hline L.c. "Pyrenees" & 470 & 348 & 376 & 344 & -5.4 & 4.24 & Senar and Borras \\
\hline L. c. "South Hills" & 87 & 86 & 58 & 61 & -1.6 & 0.07 & Benkman and Colquitt \\
\hline L. c. curvirostra & 47 & 50 & 67 & 48 & +9.8 & 2.04 & Terpstra \\
\hline L. c. "type $\mathrm{A}^{\prime \prime}$ & 8 & 5 & 5 & 7 & -20.0 & 0.99 & Van Eerde \\
\hline L. c. "type $C$ " & 27 & 23 & 23 & 30 & -10.0 & 1.16 & Van Eerde \\
\hline L. c. "type $X^{\prime \prime}$ & 17 & 21 & 15 & 14 & +7.0 & 0.32 & Van Eerde \\
\hline
\end{tabular}


even more pairings (especially assortative ones) or, preferably, longer-term selection for left- or right-crossing inbred lines (Kearsey 1998, Lynch and Walsh 1998).

Alternatively, mandible crossing may not be genetically determined. If so, any ratio of mandible crossing can be expected among offspring, independent of the mandible crossing direction of their parents. James et al. (1987) speculated that a nongenetic developmental response by juvenile birds to cone-spiraling direction is the cause of crossbill mandible crossing ratios in the wild. However, their available data did not support their hypothesis. As well, Benkman (1996) argued that mandible crossing direction is already determined in nestlings still feeding on seeds regurgitated by their parents and, thus, is not an adaptive response to exposure to their resources. He cites H. B. Tordoff, who observed that, when stimulated by gently squeezing their bills, nestling crossbills consistently abducted their lower mandible to the side to which it would cross as an adult. Thus, the asymmetry is already determined early in development, several weeks before the mandibles begin to cross and before they are used to extract seeds from cones. If development of mandible crossing direction in the egg or nestling phase is random, a 1:1 ratio of mandible crossing would be expected on average (Lynch and Walsh 1998), whereas highly significant deviations (e.g. 1:2.6 in 784 North American White-winged Crossbills; Benkman 1988) have been observed. These deviations are hard to reconcile with stochastic environmental factors determining mandible crossing direction but support a genetic basis of mandible crossing direction (Groth 1992).

Whether mandible crossing direction has no or a very small genetic basis, the situation in crossbills contrasts sharply with the mechanism determining another bimodal bill trait under selection in another finch: bill size in the Blackbellied Seed-cracker (Pyrenestes ostrinus). Smith (1993) deducted from a small number of Blackbellied Seed-cracker pairings in captivity that a single, dominant, autosomal gene determines whether bills are small or large. This contrast between Pyrenestes and Loxia testifies that despite apparent parallels between ecologically specialized species in the mechanism for maintenance of discrete phenotypic polymorphisms, determination of the polymorphisms may be widely different.

\section{Acknowledgments}

W. Janssen and L. Louwies provided data on mandible crossing direction of some pairs and offspring. Data on mandible crossing direction in wild male and female crossbills was kindly provided by C. Benkman and J. Colquitt (New Mexico State University), J. C. Senar and A. Borras (Museo Zoologia, Barcelona, Spain), Kees Terpstra (The Netherlands), and K. van Eerde (The Netherlands). The manuscript benefited from comments on previous versions by $\mathrm{C}$. Benkman, two unknown reviewers, and the editors. P. E. was financially supported by a Talentstipend from the Netherlands Organization for Scientific Research (NWO).

\section{Literature Cited}

Benkman, C. W. 1988. A 3:1 ratio of mandible crossing direction in White-winged Crossbills. Auk 105:578-579.

Benkman, C. W. 1996. Are the ratios of bill crossing morphs in crossbills the result of frequency-dependent selection? Evolutionary Ecology 10:119-126.

Benkman, C. W., and A. K. Lindholm. 1991. The advantages and evolution of a morphological novelty. Nature 349:519-520.

Edelaar, P., R. Summers, and N. Iovchenko. 2003. The ecology and evolution of crossbills Loxia spp.: The need for a fresh look and an international research programme. Avian Science 3:85-93.

Groeneveld, E. 1995. REML VCE. A multivariate multi model restricted maximum likelihood (co)variance component estimation package, version 3.2. User's guide. Institute of Animal Husbandry and Animal Behaviour, Federal Research Center of Agriculture, Mariensee, Germany.

Groth, J. G. 1992. Further information on the genetics of bill crossing in crossbills. Auk 109:383-385.

Groth, J. G. 1993. Call matching and positive assortative mating in Red Crossbills. Auk 110:398-401.

НАтсн, J. J. 1985. Lateral asymmetry of the bill of Loxops coccineus (Drepanidinae). Condor 87:546-547. 
James, P. C., T. W. Barry, A. R. Smith, and S. J. BARry. 1987. Bill crossover ratios in Canadian crossbills Loxia spp. Ornis Scandinavica 18: 310-312.

Kearsey, M. J. 1998. The principles of QTL analysis (a minimal mathematics approach). Journal of Experimental Botany 49:16191623.

Lynch, M., ANd B. Walsh. 1998. Genetics and Analysis of Quantitative Traits. Sinauer Associates, Sunderland, Massachusetts.

Merilä, J., And B. C. Sheldon. 2001. Avian quantitative genetics. Pages 179-255 in Current Ornithology, vol. 16 (V. Nolan, Jr., and C. F. Thompson, Eds.). Plenum Press, New York.

Rовв, M. 2000. Introduction to vocalizations of crossbills in north-western Europe. Dutch Birding 22:61-107.

Sмiтh, T. B. 1993. Disruptive selection and the genetic basis of bill size polymorphism in the African finch Pyrenestes. Nature 363: 618-620.

Tordoff, H. B. 1954. Social organization and behavior in a flock of captive, nonbreeding Red Crossbills. Condor 56:346-358.

Associate Editor: R. C. Fleischer 